DOI 10.15290/cnisk.2016.01.01.04

MGR URSZULA ĆWIK

Uniwersytet $w$ Białymstoku

\title{
Zagadnienie praw kobiet na łamach „Kobiety i Życia” (1970-1989)
}

\section{Streszczenie}

Prawa kobiet, rozumiane jako uprawnienia i wolności należace do kobiet i dziewcząt w danych społeczeństwach, w niektórych regionach sa zinstytucjonalizowane i wspierane przez prawo, miejscowe zwyczaje oraz zachowania, podczas gdy w innych sa ignorowane i łamane. Wynika to $z$ kilku czynników, m.in. religijnych, społecznych, ekonomicznych, kulturowych czy prawnych. Celem niniejszego artykułu jest przedstawienie problematyki zwiąanej $z$ prawami kobiet, publikowanej na łamach „Kobiety i Życia” - jednego z najpopularniejszych czasopism kobiecych okresu Polskiej Rzeczpospolitej Ludowej. Po 1970 r. i objęciu stanowiska redaktor naczelnej przez Barbarę Sidorczuk na łamach „Kobiety i Życia” coraz częściej poruszana była problematyka statusu społecznego kobiet oraz ich uprawnień w różnych dziedzinach życia publicznego. Poprzez metodę analizy zawartości prasy autorka stara się przede wszystkim, odpowiedzieć na pytanie: Jak często w publikowanych materiałach prasowych pojawiały się zagadnienia związane $z$ prawami kobiet?

Słowa kluczowe: prawa kobiet - prasa kobieca - Polska Rzeczpospolita Ludowa $\bullet$ propaganda • „Kobieta i Życie” • równouprawnienie 
THE ISSUE OF WOMEN'S RIGHTS IN “KOBIETA I ŻYCIE” (1970-1989)

\begin{abstract}
The term "women's rights" should be understood as the power and freedom enjoyed by women in society. In some countries, women's rights are supported by law and local custom, while in others they are ignored and violated. This is due to several factors: religious, social, cultural, economic or legal. The aim of this article is to present the issues of women's rights published in "Kobieta i Życie" magazine in the years 1970-1989. "Kobieta i Życie" was one of the most popular women's magazines in the Polish People's Republic. The magazine was addressed to the female intelligentsia living in cities. In 1970 Barbara Sidorczuk became the managing editor and the magazine's thematic focus shifted to the themes of social status of women, improving qualifications and their rights in various fields of social life. By applying the method of analysis of the work the author of this article attempted to answer the following questions: How often did press materials address issues of women's rights? What privileges were mentioned most often?

Keywords: women's rights - women's press - Communist era • propaganda • "Kobieta i Życie" • equality
\end{abstract}

\title{
Uwagi wstępne
}

Przez pojęcie „prawa kobiet” rozumieć należy uprawnienia i wolności przysługujące kobietom i dziewczętom w danych społeczeństwach. W niektórych regionach prawa kobiet sa zinstytucjonalizowane i wspierane przez prawo, miejscowe zwyczaje i zachowanie, podczas gdy w innych sa ignorowane i łamane. Wynika to z wielu czynników o różnorodnym charakterze: uwarunkowania religijne, kulturowe, ekonomiczne, społeczne, prawne itd. Prawa kobiet różnia się od ogólnie rozumianej kwestii praw człowieka wskazaniem uwarunkowanego historia i tradycja słabszego egzekwowania praw kobiet i dziewcząt niż praw mężczyzn i chłopców ${ }^{1}$. Współcześnie zagadnienia praw kobiet najczęściej występu-

${ }^{1}$ F. P. Hosken, Toward a Definition of Women's Human Rights, „Human Rights Quarterely” 1981, vol. 3, No. 2, s. 1-10. 
ją w kontekście integralności i autonomii cielesnej, czynnego i biernego prawa wyborczego, sprawowania funkcji publicznych, pracy, sprawiedliwej i równej $z$ mężczyznami płacy, edukacji, służby wojskowej, zawierania umów, wolności w dziedzinie rodzinnej, rodzicielskiej i religijnej².

Problematyka praw kobiet jest rozległa i obejmuje szereg dyscyplin szczególowych prawoznawstwa. $Z$ regulacjami prawnymi dotyczacymi kobiet mamy do czynienia $\mathrm{w}$ takich gałęziach prawa, jak: prawo pracy, prawo rodzinne czy prawo cywilne. Szczegółowa analiza wszystkich unormowań, dotyczących w sposób pośredni lub bezpośredni kobiet, wykraczałaby znacznie poza ramy niniejszego artykułu. Celem prezentowanej pracy jest przedstawienie zagadnień praw kobiet, publikowanych na łamach „Kobiety i Życia” w latach 1970-1989. Poprzez zastosowanie metody analizy prasy będę starała się odpowiedzieć na pytania: Jak często w publikowanych materiałach występowała tematyka praw kobiet? Które kategorie uprawnień pojawiały się najczęściej? Czy na eksponowanie konkretnych zagadnień dotyczacych praw kobiet miał wpływ ówczesny system polityczny oraz wszechobecna propaganda?

Analizując zawartość kolejnych wydań „Kobiety i Życia”, nie można zapominać, że prasa w tym okresie pełniła funkcję propagandowa, krzewiąc idee zgodne $z$ doktryna komunistyczną. Od samego początku istnienia Polskiej Rzeczpospolitej Ludowej uznana została za jeden $z$ podstawowych instrumentów przejęcia, utrzymania, sprawowania i przede wszystkim, kontroli władzy. Wykorzystujac zalety prasy drukowanej, takie jak: niska cena, aktualność, szybkość i łatwość dostępu, masowość, periodyczność oraz szeroko rozpowszechnione przekonanie o wiarygodności słowa pisanego, władze Polskiej Rzeczpospolitej Ludowej starały się kształtować nowy obraz otaczającej rzeczywistości³.

\footnotetext{
2 Women's Rights Guide, red. C. Dunning, Cambridge - MA 2007, s. 4.

$3 \mathrm{M}$. Mazur, O człowieku tendencyjnym... Obraz nowego człowieka $w$ propagandzie komunistycznej $w$ okresie Polski Ludowej i PRL 1944-1956, Lublin 2009, s. 241; Propaganda Polski Ludowej. Teki edukacyjne IPN, oprac. Paweł Kowalski [et al.] Łódź 2007, s. 7.
} 
W 1951 r. Robotnicza Spółdzielnia Wydawnicza „Prasa” zaczęła wydawać „Kobietę i Życie Praktyczne”. Dwa lata później tytuł skrócono na "Kobieta i Życie” i pod taką nazwą czasopismo wydawane było aż do 2002 r. ${ }^{4}$. W pierwszych latach ukazywania się pisma jego program i przeznaczenie czytelnicze było niewyraźne: raz kierowane do robotnicy bioracej udział w wyścigu pracy, raz do nauczycielki, urzędniczki, działaczki społecznej Ligi Kobiet lub działaczki partii. Po 1956 r. czasopismo zostało skierowane do kobiecej inteligencji mieszkającej $\mathrm{w}$ miastach. Wraz $\mathrm{z}$ upływem kolejnych lat redakcja pisma starała się przekształcać jego profil ze społeczno-poradnikowego na polityczno-społeczny dla kobiet lepiej wykształconych niż odbiorczynie "Przyjaciółki”" $Z$ badań czytelnictwa wynika, że „Kobieta i Życie” wraz z „Przyjaciółka”, „Zwierciadłem” i „Magazynem Rodzinnym” należały do najpopularniejszych periodyków kobiecych w Polskiej Rzeczpospolitej Ludowej6.

Ewolucję „Kobiety i Życia” można podzielić na kilka okresów. Ze względu na ramy czasowe przyjęte na potrzeby niniejszego artykułu należy scharakteryzować zmiany, jakie zaszły w funkcjonowaniu czasopisma od 1970 r. Najistotniejsza była zmiana redaktora naczelnego - redakcję objęła Barbara Sidorczuk. Od tego czasu coraz silniej wprowadzano tematykę statusu społecznego kobiet, ich pracy, podnoszenia kwalifikacji, awansu zawodowego, rodziny, dzieci, a także roli ojca w ich wychowywaniu. W kwietniu 1970 r. obchodzono jubileusz wydania tysięcznego numeru i $z$ tej

\footnotetext{
${ }^{4}$ Krótka przerwa w wydawaniu pisma spowodowana była wprowadzeniem stanu wojennego. Jego reaktywacja nastąpiła w kwietniu 1982 r. W 2002 r. pismo uległo zawieszeniu. Ówczesna recesja gospodarcza spowodowała spadek nakładów, sprzedaży prasy i powierzchni reklamowej, a wśród wydawców magazynów rozpoczęła się ostra walka o nisze wydawnicze, reklamodawców oraz czytelników. Czasopismo nie potrafiło dotrzymać tempa tym zmianom i uległo zawieszeniu. Sześć lat później, w październiku 2008 r. „Kobieta i Życia” ponownie ukazała się w sprzedaży i aktualnie wydawca miesięcznika jest Wydawnictwo Bauer.

5 Z. Sokół, Prasa kobieca $w$ Polsce $w$ latach 1945-1995, Rzeszów 1998, s. 104; M. Hajdo, Wizerunek kobiety jako matki, pracownika i działaczki społecznej prezentowany na łamach prasy kobiecej w latach 1948-1956, „Dzieje Najnowsze” 2006, nr 3, s. 55-56.

6 G. Wójcik, Emancypacja kobiet $w$ okresie lat 60. i 70. na łamach czasopisma „Kobieta i Życie”, „Kultura Popularna” 2014, nr 2 (40), s.119; Z. Sokół, Prasa kobieca $w$ Polsce..., op. cit., s. 104.
} 
okazji dokonano inauguracji drugiego tysiąclecia pisma „Kobieta i Życie" wydaniem osobnego numeru zadedykowanego pierwszej płci poświęcony tym, którzy naszego pisma nie czytaja, a przynajmniej nie przyznaja się do tego, czyli (...) mężczyznom ${ }^{7}$, z kolorowa fotografia aktora Jana Kobuszewskiego na okładce ${ }^{8}$. Pojawił się nowy temat - propagowanie małżeństwa partnerskiego, w którym podział obowiązków domowych miał być porównywalny, jak również problematyka życia seksualnego małżeństw.

Rok 1975 obwołany przez Organizację Narodów Zjednoczonych „Rokiem Kobiet” miał być poświęcony działaniom zmierzającym do zrównania pozycji kobiet $z$ mężczyznami w życiu politycznym, społecznym, ekonomicznym i kulturalnym. Redakcja „Kobiety i Życia" dokonała analizy dotychczasowej działalności w kwestii kobiecej. Zauważono, że kobiety w Polsce, mimo posiadania takiego samego wykształcenia jak mężczyźni, sa dyskryminowane na rynku pracy, maja duże trudności w awansach zawodowych, że jest ich mało w ciałach ustawodawczych, wykonawczych, w strukturach partyjnych, że kobiety, stanowiące przecież przeszło połowę społeczeństwa, nie mają wpływu na własne losy ${ }^{9}$.

\section{Problematyka praw kobiet w świetle „Kobiety i życia”}

Analizując treść publikacji zamieszczanych na łamach „Kobiety i Życia" na przestrzeni ponad dwudziestu lat, można było zaobserwować, że najczęściej prawa kobiet pojawiały się w kontekście jednakowych praw w dziedzinie życia ekonomicznego i społecznego. Redakcja czasopisma wielokrotnie podejmowała zagadnienia związane $\mathrm{z}$ równym traktowaniem $\mathrm{w}$ pracy czy

7 Z. Sokół, Wizerunki kobiet na łamach tygodnika „Kobieta i Życie” w latach 1946-2002, „Rocznik Prasoznawczy” 2012, R. VI, s. 22.

8 Numer 1001 (wydanie 15/1970) ukazał się pod hasłem Pod znakiem mężczyzny i dotyczył problemów, $z$ jakimi zmaga się ojciec samotnie wychowujący dziecko. Zofia Sokół w jednym ze swoich opracowań podaje, że ponad 30 procent mężczyzn prenumerowało i czytało w tamtym okresie „Kobietę i Życie” - co według niej stanowiło powód wprowadzenia na łamy pisma stałej rubryki „Mężczyzna i Życie".

9 Z. Sokół, Prasa kobieca w Polsce..., op. cit., s. 106-108; Z. Sokół, Kobieta i Życie (1945-2002), „Studia Bibliograficzne Akademii Świętokrzyskiej” 2005, t. 9, s. 6. 
otrzymywaniem jednakowej płacy za jednakowa pracę. Ale tematem, który najbardziej był eksponowany, jeśli chodzi o prawa ekonomiczne kobiet, była kwestia awansów.

Barbara Sidorczuk już w 1965 r., czyli pięć lat przed objęciem redakcji „Kobiety i Życia”, dzieliła się z czytelniczkami swoimi, niezbyt optymistycznymi refleksjami, dotyczacymi kwestii awansowania kobiet pracujących zawodowo. Pisała:

Jesteśmy świadkami dość dziwnej sytuacji. Połowa wykształconych obywateli $z$ natury niejako jest słabiej wykorzystywana. W krajach bardziej rozwiniętych od naszego nie ma tak bogatego zaplecza w postaci wysoko kwalifikowanych kobiet pracujacych zawodowo, a przecież śmielej wprowadza się je na wysokie stanowiska. U nas dobre sa do pracy, gorsze do kierowania i decydowania. Także w profesjach, w których stały się potęga, szefami pozostaja zwykle mężczyźni. Np. w przemyśle włókienniczym, handlu, szkolnictwie. Połowa lekarzy w Polsce to kobiety. Stanowiska, wymagajace znajomości zawodu powierza się im chętnie, np. kierowników przychodni czy ordynatorów, zatem nie brak wiedzy czy doświadczenia jest hamulcem awansu. Ale tam, gdzie zapadaja decyzje wpływajace na kształt i oblicze naszego życia, jest ich jak na lekarstwo. Np. w ministerstwach dyrektorzy, wicedyrektorzy departamentów, samodzielni naczelnicy, to $z$ reguły mężczyźni. Kobiety stanowią $\mathrm{w}$ tym towarzystwie niewiele ponad 4 proc. Ale już główni specjaliści w departamentach, doradcy itp. w 24 procentach sa kobietami. Czyli nie o fachowość tu idzie ${ }^{10}$.

W dalszej części swojego artykułu wskazywała przyczyny niechętnego awansowania kobiet. Za jedne $z$ głównych uznała bariery psychologiczne i obyczajowe. Podkreślała, że obiegowe przekonanie, iż kobieta nie nadaje się do kierowania, czy decydowania wynika przede wszystkim $z$ tradycji, ze świadomości społecznej, $z$ faktu, że nie było wzorów do naśladowania ${ }^{11}$.

W materiałach publikowanych na łamach „Kobiety i Życia” wielokrotnie zwracano uwage na brak kobiet na wyższych szczeblach zawodowych. W latach 70 . XX w. Polki stanowiły większość

10 B. Sidorczuk, Awanse, „Kobieta i Życie” 1965, nr 3, s. 5, 8.

11 Ibidem. 
zatrudnionych w wielu działach gospodarki narodowej, jednak na stanowiskach kierowniczych było ich niewiele ${ }^{12}$. Potwierdzeniem tego zjawiska był chociażby artykuł Kłopoty $z$ awansem, opisujacy sytuację kobiet pełniących kierownicze funkcje w spółdzielniach spożywców, w którym można było przeczytać:

W spółdzielczości bowiem, podobnie jak w wielu innych działach gospodarki narodowej, mimo że wśród ogółu zatrudnionych kobiety stanowią większość, na stanowiskach kierowniczych jest ich jak na lekarstwo. Im wyżej, tym ich mniej (...) Procent kobiet na niższych i średnich stanowiskach kierowniczych jest proporcjonalny do stanu zatrudnienia, ale już zupełnie niewielka ich liczba zajmuje stanowiska prezesów i wiceprezesów zarząów spółdzielni i ich oddziałów ${ }^{13}$.

Jednak na łamach „Kobiety i Życia” wielokrotnie podkreślano, że podejmowane sa starania, które maja zmienić otaczająca rzeczywistość. Po przytoczeniu danych liczbowych, niekorzystnych $z$ punktu widzenia kobiet pracujących zawodowo, można było przeczytać o inicjatywie, jaka podjął zarząd „Społem”:

W jaki sposób kobieta prezes rozwiąuje sprawę obowiąków domowych i rodzinnych, aby nie kolidowały $z$ obowiazkami zawodowymi? $\mathrm{Na}$ ten temat będa dyskutować kobiety pełniące najwyższe, kierownicze funkcje w spółdzielni spożywców, na naradzie zorganizowanej przez zarząd „Społem”. Organizatorzy narady zakładaja, że dyskusja ta pomoże kobietom szefom, zwłaszcza w niełatwych sprawach godzenia pracy zawodowej $z$ obowiazkami domowymi. A może ta wymiana doświadczeń i późniejsza popularyzacja właściwych metod wpłynie na dalszy awans kobiet w zawodzie? Takie nadzieje mają Rada i zarząd „Społem”14.

Ponadto w „Kobiecie i Życiu” wielokrotnie zamieszczano listy czytelniczek, które pisały do redakcji o swoich negatywnych od-

12 Główny Urząd Statystyczny (GUS), Kobieta $w$ Polsce, Warszawa 1985, s. 3133; A. Kurzynowski, Aktywność zawodowa kobiet w 40-leciu PRL [w:] Kobiety polskie, red. E. Konecka, Warszawa 1986, s. 319-322.

13 M. B., Kłopoty z awansem, „Kobieta i Życie” 1973, nr 7, s. 8.

14 Ibidem. 
czuciach zwiąanych $z$ traktowaniem ich przez pracodawców czy uregulowaniami prawnymi, dotyczacymi pracy zawodowej kobiet. Autorka jednego $\mathrm{z}$ takich listów była Nie pracujaca matka, która opowiadała o konieczności zrezygnowania $z$ pracy na rzecz wychowania i opieki nad swoim chorym dzieckiem. Pisała, że poza normalnymi zajęciami gospodarskimi, które spoczywały dotąd na jej barkach, poza pielęgnacją i wychowywaniem dzieci przejęła jeszcze obowiązki, których wcześniej nie miała: szycie odzieży, drobne naprawy domowe. Ponieważ nie pracowała, nie mogła już za te usługi zapłacić, musiała wykonywać je sama. W swojej wypowiedzi podkreślała, że nie skarży się na swoja sytuację życiowa, gdyż dostrzega jej dodatnie strony: zadbane dzieci oraz idealnie funkcjonujacy dom ${ }^{15}$. Jednak w dalszej części wyraźnie zauważyć można rozżalenie autorki listu:

Czuję się nagle obywatelem drugiej kategorii! Gdy pracowałam, byłam obywatelem pełnoprawnym. Należałam do zwiazku zawodowego, pozostawałam niejako pod opieka Rady Zakładowej. Należał mi się urlop, wczasy, każdy rok mojej pracy szedł na konto przyszłej emerytury. Teraz czuję się w jakimś sensie samotna, wyobcowana ze społeczeństwa. Wszystko, co mi się należy, związane jest $\mathrm{z}$ osoba mojego męża. Za pracę nie pobieram wynagrodzenia, nie należy mi się urlop, wczasy mogę dostać jako „przyczepka” do męża. Moich praw nie broni żaden zwiazek zawodowy. Co gorzej: lata mojej pracy jako gospodyni domowej nie liczą się do renty. Gdy do pracy powrócę - a mam ten zamiar - strace prawo do dłuższego urlopu wypoczynkowego, będę musiała zarabiać na niego od początku. A czy w ogólnym rozrachunku społecznym moja praca w domu jest naprawdę tak nieważna? ${ }^{16}$

Kategoriami praw kobiet, które była równie często poruszane na łamach „Kobiety i Życia” były te związane $z$ równymi prawami politycznymi oraz dostępem do stanowisk publicznych. Jednak to, co odróżniało prawa ekonomiczne od praw politycznych $\mathrm{w}$ świetle analizowanego czasopisma, to okres ich występowania. Już od lat 60. XX w. zagadnienia związane $z$ równym traktowa-

15 Do redakcji - Nie pracujace, „Kobieta i Życie” 1970, nr 17, s. 3.

16 Ibidem. 
niem kobiet w pracy zawodowej były obecne w „Kobiecie i Życiu”. Natomiast tematyka obecności kobiet w życiu politycznym pojawiała się jedynie sporadycznie, najczęściej przy okazji wyborów do rad narodowych. Dopiero od początku lat 80. XX w. można było zaobserwować, że coraz większa liczba materiałów prasowych dotyczy aktywności kobiet w życiu publicznym i politycznym.

Problematyka dostępu kobiet do sprawowania funkcji publicznych zaczyna coraz częściej pojawiać się od 1980 r. Najlepszym tego potwierdzeniem był, opublikowany w 1981 r., materiał będacy swoistą refleksja autorki na temat IX Zjazdu Komitetu Centralnego Polskiej Zjednoczonej Partii Robotniczej:

Pierwsze padłyśmy ofiarami demokracji - zagaiła przewodniczaca Rady Eugenia Kemparowa. - Odnowa pociagnęła za soba eliminację kobiet $\mathrm{z}$ zajmowanych stanowisk! Drogie towarzyszki, degradacja społeczna kobiety postępuje, odejście od klucza podczas wyborów delegatów na IX Zjazd spowodowało, że zaledwie 5 proc. delegatów stanowia kobiety! A czy nie ma wśród nas zdolnych? Madrych? Godnych być delegatkami? Ale - jak mówię - kobiety przegrały w wyborach. Wstecznictwo i uprzedzenia najwyraźniej doszły do głosu ${ }^{17}$.

W dalszej części relacji zjazdowych Barbara Szczepuła przywoływała wypowiedź redaktor naczelnej Barbary Sidorczuk, która mówiła m.in. o tym, że

(...) w naszym kraju istnieje męski model władzy, natomiast kobiety sa - jej zdaniem - proletariatem współczesnej Polski. Manipuluje się nimi dowolnie: w okresie prosperity przyznaje się im prawa obywatelskie, a podczas kryzysów odsyła się do domu. - Tak wygląda równość zagwarantowana Konstytucją ${ }^{18}$.

Należy zwrócić uwagę na słowa wypowiedziane przez Barbarę Sidorczuk. W analizowanym okresie pogląd o manipulowaniu Polkami przez komunistyczne władze podzielało wiele kobiet, chociażby prof. dr Stefania Dzięcielska-Machnikowska, kierownik

\footnotetext{
17 B. Szczepuła, Bunt kobiet, „Kobieta i Życie” 1981, nr 17, s. 3.

18 Ibidem.
} 
Zakładu Socjologii Zawodu Uniwersytetu Łódzkiego, która w wywiadzie $z$ Natalią Iwaszkiewicz mówiła:

Twierdzę proszę pani, że w zależności od potrzeb, kobietami najzwyczajniej w świecie się manipuluje. Raz to okrzyk: Irena do domu, innym razem: dziewczęta na traktory! Skóra na mnie cierpnie, kiedy czytam, że budujemy dla naszych dzielnych, kochanych kobiet żłobki i przedszkola. Czy pani albo ja wybieramy się do żłobka, powiedzmy, chyba nie? Moga się tam ewentualnie znaleźć nasze dzieci. A my będziemy mogły wyjść z domu i pójść do pracy ${ }^{19}$.

Problematykę niskiej aktywności kobiet w życiu politycznym najczęściej podejmowała redaktor naczelna „Kobiety i Życia” Barbara Sidorczuk. W artykule Ławy poselskie nie tylko dla mężczyzn niejako nawiazywała do swojej publikacji Awanse z 1965 r. Pisała:

Gdy przed dwudziesty laty „odkrywałam” w roli dziennikarki tzw. problem kobiecy, wnioski były zaskakujace. Słowo dyskryminacja wydawało się zbyt ciężkim zarzutem, ale fakty sugerowały właśnie takie stwierdzenie. Kobiety garnęly się masowo do szkół i uczelni, zdobywały kwalifikacje i były chwalone jako solidne pracownice. A mężczyźni awansowali20.

W dalszej części tekstu odwoływała się do zjawisk, jakie panowały w tamtym okresie na świecie, gdzie według niej zaobserwować można było

(...) swoista zmianę obyczaju. Kobiety kieruja państwami, licza się w polityce międzynarodowej, sa poważnymi partnerami w wytyczaniu losów świata. Takie myślenie nigdy nie przedostało się przez polskie granice, gdzie kobieta chętniej czczona jest w roli męczennicy niż partnerki we współdecydowaniu o teraźniejszości kraju. Ja się ceni $z$ reguly za serce - a nie za rozum, chociaż rozum, realizm i skłonność do praktycznego widzenia otaczającej codzienności przypisywany jest kobietom przy różnych okazjach ${ }^{21}$.

\footnotetext{
19 N. Iwaszkiewicz, Kobiety $w$ drugim gatunku, „Kobieta i Życie” 1985, nr 27, s. 2.

20 B. Sidorczuk, Ławy poselskie nie tylko dla mężczyzn, „Kobieta i Życie” 1985, nr 26, s. 2.

21 Ibidem.
} 
Wskazując specyfikę ówczesnej rzeczywistości oraz zalety i mocne strony kobiet, starała się utwierdzać czytelników w przekonaniu, że Polek powinno być o wiele więcej w gremiach ustawodawczych naszego kraju:

Mamy obecnie czasy, gdy liczy się realizm, oglądanie się na drobiazgi, a nie efektowna fantazja, wizjonerski polot, gesty i efekciarstwo. Skrupulatność kobiet, które codziennie musza zmierzyć się z trudnościami, to cechy które je predestynuja do przenoszenia ważnych doświadczeń na forum, gdzie codzienność państwa się decyduje. Od tego czy kobiety będą w Sejmie zależy bardzo wiele. Nie tylko ich samopoczucie jako obywatelek, ale i to, czy parlament następnej kadencji będzie blisko, bardzo blisko życia codziennego zwykłych ludzi22.

W latach 70. XX w. obok zagadnień praw kobiet w aspekcie ekonomiczno-społecznym oraz sporadycznie występujących praw publiczno-politycznych pojawiała się także problematyka równych praw w zakresie ich wolności w dziedzinie rodzinnej i rodzicielskiej.

W pierwszej połowie lat siedemdziesiatych „wybuchła” na łamach prasy tzw. tematyka rodzinna. Wyjątkowe namiętności budzily rozwody. I nic dziwnego, skoro - wzrastająca z roku na rok - liczba rozbitych rodzin stawała się rzeczywistym problemem społecznym ${ }^{23}$.

W latach 70. panowało przekonanie, że rodzina o silnej wewnętrznej spoistości, połączona więzią emocjonalna, była zdolna przetrwać wiele przeciwności. Rozbicie rodziny to zło konieczne. Za mniejsze zło uznawane były rozwody $z$ powodu znęcania się współmałżonka, alkoholizmu, zaniedbywania dzieci czy opuszczenia rodziny. W odpowiedzi na prośby o radę, czy rozwieść się $z$ mężem, redakcja odpowiadała najczęściej, by czytelniczki jeszcze raz przemyślały ten krok, gdyż rozwód najbardziej dotyka

22 Ibidem.

23 Polityka rodzinna, „Kobieta i Życie” 1980, nr 9, s. 5; zob. GUS, Kobieta $w$ Polsce, s. 55-59; D. Markowska, Rola kobiety $w$ polskiej rodzinie [w:] Kobiety polskie... op. cit., s. 202-203. 
dzieci i pozostawia trwały ślad w ich psychice i osobowości24. „Kobieta i Życie” upowszechniała przekonanie, że

(...) nie wolno nigdy rezygnować, unosić się ambicją i żądać rozwodu lub pochopnie zgadzać się na rozwód. Często jesteśmy zbyt honorowi - my mężczyźni i kobiety - dajemy zgodę na rozwód bez zastanowienia się, gdy tylko stwierdzimy, że jesteśmy oszukani, zdradzeni czy choćby tylko zaniedbywani ${ }^{25}$.

W materiałach dotyczących rozwodów akcentowano fakt, że redakcja nie jest zwolenniczka takiego rozwiązania. Jednocześnie nie potępiano takiej decyzji, zwracając uwagę, iż w większości przypadków było to zło konieczne i kobieta, podejmując taką decyzję, nie miała innego wyjścia. Zatem rozwód przedstawiano jako uprawnienie Polek, $z$ którego korzystały rozsądnie, mając na względzie również, albo nawet przede wszystkim, dobro swoich dzieci.

Kategoria praw, która występowała najrzadziej w analizowanym okresie, była kwestia autonomii i integralności cielesności. Jeśli już, to pojawiała się jako komentarz do przyjętej w 1956 r. Ustawy o warunkach dopuszczalności przerywania ciaży. Jak można było wywnioskować $z$ analizy materiałów publikowanych na łamach "Kobiety i Życia” - kilkanaście lat po wprowadzeniu owej ustawy spotkała się ona $z$ prawie pełną akceptacją społeczna. Świadczyć o tym mogło podsumowanie wyników ankiety, przeprowadzonej przez redakcję w 1974 r., w której czytamy:

89 proc. jest zdania, że uchylenie ustawy spowoduje pogorszenie warunków bytowych, zmniejszy liczbę zabiegów w placówkach służby zdrowia, a zwiększy zjawisko nielegalnego ich wykonywania. 11 proc. uważa, że uchylenie ustawy wpłynie na poprawę stanu zdrowia kobiet. 63 proc. wypowiada się za utrzymaniem ustawy, 30 proc. zaś za jej modyfikacją, jeżeli chodzi o pierwszą ciążę. Natomiast 7 proc. wypowiada się za jej uchyleniem ${ }^{26}$.

${ }^{24}$ Z. Sokół, Prasa kobieca $w$ Polsce..., op. cit., s. 353; F. Adamski, Konflikty matżeńskie i ich źródła na łamach „Kobiety i Życia”, „Zeszyty Prasoznawcze” 1978, nr 1 (75), s. 27-28.

25 Najpierw pomyśl, później wnieś pozew, „Kobieta i Życie” 1972, nr 44, s. 15.

${ }^{26}$ Za i przeciw ustawie, „Kobieta i Życie” 1974, nr 13, s. 7. 
Zagadnienia praw kobiet na łamach „Kobiety i Życia” pojawiały się również $\mathrm{w}$ formie reportaży $\mathrm{z}$ zagranicy - swoistych doniesień zza wschodniej granicy lub z Zachodu. Właśnie w tych materiałach najwyraźniej widoczna była panująca wówczas propaganda. W artykule o wymownym tytule Prawdziwy awans (notatki $z$ NRD) Danuta Sochacka prezentowała Niemiecką Republikę Demokratyczna jako kraj, w którym panowały idealne warunki do rozwoju zawodowego kobiet, ich karier oraz awansów. Rzeczywistość za naszą zachodnią granicą opisywała słowami:

W NRD mówi się otwarcie: niemożliwe byłoby osiagniecie w tym kraju takich rezultatów gospodarczych, niemożliwa byłaby jego odbudowa i rozwój - gdyby nie udział kobiet pracujących ${ }^{27}$.

W dalszej części przytoczyła fragment uchwały jednego $z$ Kongresów Kobiet NRD:

Kobiety maja prawo powiedzieć: istnienie i rozwój Niemieckiej Republiki Demokratycznej jest także naszym dziełem. Ale i my same rosłyśmy wraz z naszym państwem, życie kobiet wszystkich warstw społecznych uległo gruntownej przemianie. Po raz pierwszy przeżywamy radość twórczego współdziałania, twórczego współmyślenia ${ }^{28}$.

Ponadto w artykule podkreślała, iż to właśnie w NRD nastapila realna zmiana stosunku kobiet do podejmowania przez nie pracy zawodowej. Niemki zastapiły słowo muszę słowem chce i od wielu już lat ich aktywność zawodowa sprawiała im ogromną radością i satysfakcję.

Inaczej bowiem pracuje kobieta, zmuszona do tego życiowa koniecznościa, inaczej zaś ta, która swa pracę lubi, ceni, rozumie jej sens, widzi przed sobą możliwości rozwoju i awansu. Inaczej pracuje, inne jest jej samopoczucie, inna jest ranga społeczna jej pracy ${ }^{29}$

- pisała Sochacka.

27 D. Sochacka, Prawdziwy awans (notatki z NRD), „Kobieta i Życie” 1970, nr 5, s. 2,10 .

28 Ibidem.

29 Ibidem. 
Innym potwierdzeniem tego, że peerelowska propaganda nie ominęła prasy kobiecej, był wywiad z przewodnicząca Komitetu Kobiet Mongolskich L. Pagmadulam. Agnieszka Metelska zaczęła go słowami:

Mongolia jest takim dziwnym krajem, który prosto $\mathrm{z}$ feudalizmu wskoczył w socjalizm a więc omijając jedna formację ustrojowa, jaka jest kapitalizm. Jak w tej sytuacji wygląda równouprawnienie Mongołek?30

Dalej można było przeczytać wyczerpująca odpowiedź przewodniczącej, która niemalże w samych superlatywach wypowiadała się o sytuacji kobiet w jej kraju:

Równouprawnienie rozpoczyna się od naszej konstytucji, a szczegółowo określane jest różnymi aktami prawnymi. I jest to rzeczywiste równouprawnienie. Kobiety maja możliwość zdobywania takiego samego wykształcenia jak mężczyźni, tak samo korzystaja $z$ naszych zdobyczy socjalistycznych, otrzymuja za swoja pracę taka samą zapłate jak mężczyźni, sa jednakowo zaszczycane medalami, odznaczeniami państwowymi. Przed rewolucja zacofanie kobiet było bardzo duże. Żadna nie umiała czytać ani pisać. Teraz analfabetyzm zlikwidowaliśmy całkowicie ${ }^{31}$

- zapewniała na łamach „Kobiety i Życia”.

Przy okazji prezentowania pełni praw, jakimi rzekomo dysponowały kobiety żyjące w państwach socjalistycznych, starano się równocześnie przedstawiać problemy, $z$ jakimi zmagały się $n p$. Amerykanki. Przywoływano dane liczbowe, które potwierdzać miały niska aktywność publiczną kobiet w Stanach Zjednoczonych Ameryki.

Na 435 członków Izby jest w Kongresie 9 kobiet. Tylko 1 procent sędziów federalnych stanowia w USA kobiety; 1 procent kobiet jest wśród inżynierów; adwokatów i prokuratorów razem - 3 procent ogółu; wśród wszystkich pracowników naukowych jest 9 procent

30 A. Metelska, Mongołki i równouprawnienie, „Kobieta i Życie” 1983, nr 11, s. 13.

31 Ibidem. 
kobiet. Wśród lekarzy -7 procent. Nawet tradycyjnie w innych krajach sfeminizowany zawód nauczycielski zaczyna być mniej dostępny ${ }^{32}$

- w taki sposób sytuację za oceanem opisywała Maria Pińska.

Według autorek cytowanych fragmentów „Kobiety i Życia” ustrój socjalistyczny był najbardziej korzystny z punktu widzenia wypracowania rzeczywistego równouprawnienia kobiet.

\section{Podsumowanie}

Biorąc pod uwage zawartość kolejnych wydań „Kobiety i Życia” ukazujących się w latach 1970-1989, zagadnienia praw kobiet stanowiły znaczną część wszystkich materiałów publikowanych na łamach czasopisma. Jednak nie był to temat wiodacy w czasopiśmie nadal ukazywały się liczne artykuły dotyczace mody, urody, rozrywki oraz dział listów i porad. Gdy w 1970 r. redakcję pisma objęła Barbara Sidorczuk, „Kobieta i Życie” starała się zmienić swój charakter na polityczno-społeczny. Zaczęto wprowadzać tematykę statusu społecznego kobiet, ich kwalifikacji i pozycji w społeczeństwie. Jednak pomimo starań redaktor naczelnej oraz całego zespołu, czasopismo nigdy nie pozbyło się elementów typowych dla prasy społeczno-poradnikowej.

Prawa kobiet publikowane w „Kobiecie i Życiu” najczęściej należały do kategorii praw ekonomiczno-społecznych. Pojawiały się podczas całego analizowanego dwudziestolecia, dotyczac zazwyczaj kwestii zwiazanych $z$ uprawnieniami pracowniczymi kobiet, ich awansów czy otrzymywania równej z mężczyznami płacy. $\mathrm{Na}$ łamach pisma zastanawiano się, dlaczego kobiety stanowiły mniejszość na kierowniczych stanowiskach oraz jakie były powody ich niechętnego awansowania.

Nieco rzadziej poruszana była problematyka równych praw politycznych oraz dostępu do stanowisk publicznych. Trzeba jednak zaznaczyć, że w latach 70. XX w. nie odnajdziemy licznych

32 M. Pińska, Prawa dla „większej połowy”, „Kobieta i Życie” 1970, nr 26, s. 2. 
materiałów poświęconych temu zagadnieniu. Tematyka aktywności publicznej i udziału w życiu politycznym naszego kraju, zaczęła pojawiać się dopiero od początku lat 80., a prawdziwy jej rozwój można kojarzyć $z$ latami przed transformacja ustrojową 1989 r..

Dekadę wcześniej łamy „Kobiety i Życia” wypełniła szeroko rozumiana problematyka rodzinna. Redakcja czasopisma wiele miejsca poświęciła tematowi rozwodów, co wydaje się być odzwierciedleniem tendencji panujących $\mathrm{w}$ społeczeństwie polskim tamtego okresu. Rozwód $z$ perspektywy kobiety przedstawiano jako jej prawo, z którego korzysta świadomie, nie podejmując pochopnych decyzji i mając na uwadze przede wszystkim dobro dzieci. Tematyka równych praw w zakresie wolności Polek w dziedzinie rodzinnej i rodzicielskiej pojawiała się równie często, jak w latach 80. zagadnienia związane $z$ aktywnościa w sferze publicznej i politycznej.

W omawianym okresie najmniej miejsca zajmowały publikacje dotyczące autonomii i integralności cielesnej kobiety. Wystapiły jedynie w kilku krótkich wzmiankach, jako komentarze do Ustawy o warunkach dopuszczalności przerywania ciaży. Można przypuszczać, że wynikało to wyłącznie $z$ powodu przyjętych ram czasowych, gdyż w latach 1950-1960 na łamach „Kobiety i Życia” toczyła się żywa dyskusja, najpierw na temat wprowadzenia ustawy, a następnie o jej przyszłości i wcielaniu w peerelowską rzeczywistość.

Po analizie zawartości czasopisma można stwierdzić, że również „Kobieta i Życie” pełniła funkcje propagandową. Doskonale widać to na przykładzie reportaży traktujaccych o sytuacji kobiet za granicą. Czytelniczki pisma starano się przekonać, iż rzeczywiste równouprawnienie kobiet mogło istnieć tylko w krajach socjalistycznych. Jednocześnie wskazywano negatywne strony ustroju kapitalistycznego. Działania propagandowe prowadzone na łamach „Kobiety i Życia” miały jednak charakter pośredni i nie można zapominać o znaczącej roli pisma, jaka pełniło w kwestii uświadamiania kobiet na temat przysługujących im praw i wolności. 


\section{Bibliografia}

\section{Prasa}

Iwaszkiewicz N., Kobiety w drugim gatunku, „Kobieta i Życie” 1985, nr 27. Klonowska A., Polityka rodzinna, „Kobieta i Życie” 1980, nr 9.

M. B., Kłopoty z awansem, „Kobieta i Życie” 1973, nr 7.

Metelska A., Mongołki i równouprawnienie, „Kobieta i Życie” 1983, nr 11. Najpierw pomyśl, później wnieś pozew, „Kobieta i Życie” 1972, nr 44.

Pińska M., Prawa dla „większej połowy”, „Kobieta i Życie” 1970, nr 26.

Polityka rodzinna, „Kobieta i Życie” 1980, nr 9.

Rozwód w sązie, „Kobieta i Życie” 1980, nr 8.

Sandecka L., Nieprzystosowani, „Kobieta i Życie” 1975, nr 44.

Sidorczuk B., Awanse, „Kobieta i Życie” 1965, nr 3.

Sidorczuk B., Ławy poselskie nie tylko dla mężczyzn, „Kobieta i Życie” 1985, nr 26.

Sochacka D., Prawdziwy awans (notatki z NRD), „Kobieta i Życie” 1970, nr 5.

Szczepuła B., Bunt kobiet, „Kobieta i Życie” 1981, nr 17.

Za i przeciw ustawie, „Kobieta i Życie” 1974, nr 13.

\section{Opracowania}

Adamski F., Konflikty małżeńskie i ich źródła na łamach „Kobiety i Życia”, „Zeszyty Prasoznawcze” 1978, nr 1 (75), ISSN 0555-0025.

Główny Urząd Statystyczny, Kobieta w Polsce, Warszawa: Zarząd Wydawnictw Statystycznych i Drukarni, 1985.

Hajdo M., Wizerunek kobiety jako matki, pracownika i działaczki społecznej prezentowany na łamach prasy kobiecej w latach 1948-1956, „Dzieje Najnowsze” 2006, nr 3, ISSN 0419-8824.

Hosken F. P., Toward a Definition of Women's Human Rights, „Human Rights Quarterely”1981, vol. 3, No. 2, ISSN 0275-0392.

Kurzynowski A., Aktywność zawodowa kobiet w 40-leciu PRL [w:] Kobiety polskie, red. Elżbieta Konecka, Warszawa: Spółdzielnia Wydawniczo-Handlowa „Książka i Wiedza”, 1986, ISBN 8305116247.

Madeyska J., Uprawnienia kobiety pracujacej, Warszawa: Wydaw. Prawnicze, 1986, ISBN 83-219-0330-4.

Markowska D., Rola kobiety $w$ polskiej rodzinie [w:] Kobiety polskie, red. Elżbieta Konecka, Warszawa: Spółdzielnia Wydawniczo-Handlowa „Książka i Wiedza”, 1986, ISBN 8305116247. 
Mazur M., O człowieku tendencyjnym: obraz nowego człowieka w propagandzie komunistycznej w okresie Polski Ludowej i PRL 1944-1956, Lublin: Wydawnictwo Uniwersytetu Marii Curie-Skłodowskiej, 2009, ISBN 978-83-227-2989-2.

Propaganda Polski Ludowej, oprac. Paweł Kowalski [et al.], Łódź: Instytut Pamięci Narodowej KŚZPNP, 2007, ISBN 978-83-60464-58-8.

Sokół Z., Kobieta i Życie (1945-2002), „Studia Bibliograficzne Akademii Świętokrzyskiej" 2005, t. 9, ISSN 2449-898X.

Sokół Z., Prasa kobieca $w$ Polsce $w$ latach 1945-1995, Rzeszów: Wydaw. Wyższej Szkoły Pedagogicznej, 1998, ISBN 83-87288-46-2.

Sokół Z., Wizerunki kobiet na łamach tygodnika „Kobieta i Życie” w latach 1946-2002, „Rocznik Prasoznawczy” 2012, R. 6, ISSN 1897-5496.

Women's Rights Guide, red. C. Dunning, Cambridge MA: Bernard Koteen Office of Public Interest Advising, 2007.

Wójcik G., Emancypacja kobiet w okresie lat 60. i 70. na łamach czasopisma „Kobieta i Życie”, „Kultura Popularna” 2014, nr 2 (40), ISSN 1644-8340. 